\title{
Aluminium hydro(oxide)-based (AO) adsorbent for defluoridation of drinking water: Optimisation, performance comparison, and field testing
}

\author{
Eyobel Mulugeta ${ }^{1}$, Feleke Zewge ${ }^{1 *}$, C Annette Johnson ${ }^{2}$ and Bhagwan Singh Chandravanshi ${ }^{1}$ \\ 'Department of Chemistry, Faculty of Science, Addis Ababa University, PO Box 1176, Addis Ababa, Ethiopia \\ ${ }^{2}$ Swiss Federal Institute of Aquatic Science and Technology (Eawag), 8600 Dübendorf, Switzerland
}

\begin{abstract}
In this study, the performance of different aluminium hydroxide-based adsorbents was compared in terms of fluoride adsorption capacity, potential for repetitive regeneration, surface acidity and surface site concentrations. The adsorbents were aluminium hydro(oxide) $(\mathrm{AO})$, activated alumina $(\mathrm{AA})$, and pseudoboehmite $(\mathrm{PB})$. The $\mathrm{AO}$ adsorbent was synthesised at different $\mathrm{OH}: \mathrm{Al}$ ratios to optimise the fluoride adsorption capacity. The $\mathrm{AO}$ was pilot tested in a rural community in the Ethiopian Rift Valley where groundwaters are heavily enriched with fluoride. The maximum fluoride uptake was achieved for the $\mathrm{AO}$ adsorbent synthesised at $\mathrm{OH}: \mathrm{Al}$ ratios between 2.5 and 2.7. The fluoride adsorption capacity of the adsorbents determined from mini-column studies was found to be 10.6, 1.9, and $2.4 \mathrm{mg} / \mathrm{g}$ for $\mathrm{AO}, \mathrm{AA}$, and $\mathrm{PB}$, respectively. This significant difference in fluoride adsorption capacity is strongly related to the surface acidity and surface site concentration. The surface acidity $(1.57 \mathrm{meq} / \mathrm{g})$ and surface site concentration $(0.74 \mathrm{meq} / \mathrm{g})$ for $\mathrm{AO}$ is higher than that for AA and PB. The elemental composition analysis showed that $\mathrm{AO}$ has a lower $\% \mathrm{Al}_{2} \mathrm{O}_{3}$ content than $\mathrm{AA}$ and $\mathrm{PB}$, but higher sulphate (19.4\%) and iron (2.2\%) content. High resolution ${ }^{27} \mathrm{Al}$ Magic Angle Spinning Nuclear Magnetic Resonance ( ${ }^{27} \mathrm{Al}$ MAS NMR) spectra of $\mathrm{AO}, \mathrm{AA}$, and $\mathrm{PB}$ were recorded, to analyse the coordination geometry of solid $\mathrm{Al}$ species and the results showed that aluminium is coordinated octahedrally and tetrahedrally in all cases. Regeneration experiments showed that AA and PB can be regenerated for more than 3 cycles, whereas the potential for regeneration of $\mathrm{AO}$ for more than 3 cycles is limited. The results from a community defluoridation plant showed that fluoride in the feed water $(8-10 \mathrm{mg} / \ell)$ is removed below $0.1 \mathrm{mg} / \ell$. The average adsorption capacity was determined to be $2.11 \mathrm{mg} / \mathrm{g}$ based on continuous field monitoring results obtained until the fluoride content in the treated water exceeded the breakthrough value of $1.5 \mathrm{mg} / \ell$. No major operational problems and complaints from the beneficiaries were experienced during operation.
\end{abstract}

Keywords: fluoride, adsorption, surface acidity, regeneration, defluoridation, Ethiopia

\section{INTRODUCTION}

The level of fluoride in drinking water is a very important physicochemical factor, which must be considered when assessing water quality for human consumption. According to the World Health Organization the maximum acceptable concentration of fluoride ions in drinking water is $1.5 \mathrm{mg} / \ell$ (WHO, 2011). While a low daily dose of fluoride is considered to be responsible for preventing dental caries; a higher daily dose has been linked to permanent dental and skeletal fluorosis (Guo and Guo, 2013). Many water sources in Ethiopia contain fluoride at elevated concentrations of up to $26 \mathrm{mg} / \ell$ (Kloos and Tekle-Haimanot, 1999). According to estimates of the Ethiopian Ministry of Water Resources, more than 11 million people in the Ethiopian Rift Valley rely on drinking water contaminated by fluoride (Adeno et al., 2014).

In areas where alternative options are not feasible, as in the case of most tropical regions of developing countries, defluoridation of drinking water might be the most prioritised option. The choice of defluoridation technology depends on

\footnotetext{
To whom all correspondence should be addressed.

ifi +25 1111239466; fax: +25 1111239470;

e-mail: fbeshah@yahoo.com

Received 9 November 2013; accepted in revised form 17 December 2014.
}

cost effectiveness, ease of operation, water composition, taste of water, quality of treated water and management of wastes produced. Community solutions have strong advantages over household solutions in terms of monitoring and maintenance, but these can be offset by higher investment and lack of ownership (Bregnhoj, 1997).

Defluoridation methods can be broadly divided into 4 categories according to the main removal mechanism: (co)precipitation, ion exchange, adsorption and physical separation (Sneha et al., 2012). Fluoride removal through adsorption onto various materials is the most promising in terms of running costs and ease of operation. The choice of adsorptive medium depends on fluoride uptake capacity, the possibility of regeneration, the number of useful cycles and the end-of-life fate (Osterwalder et al., 2014).

Several adsorbent materials have been tested in an attempt to identify an efficient and economical defluoridating material (Sneha et al., 2012). Activated alumina (AA) has been extensively studied for years for fluoride removal from drinking water. Defluoridation processes based on AA have been used at both community and domestic levels. Ghorai and Pant (2004, 2005) have found that removal was the result of ion-exchange as well as adsorption processes. The fundamental interfacial properties of aluminium hydroxide are the protonation of surface hydroxyl groups resulting in the development of surface charge (Goldberg et al., 1996). At solution $\mathrm{pH}$ values 
below 6 the surface of AA has a positive charge and thus a great capacity for fluoride adsorption. In the neutral $\mathrm{pH}$ range the affinity of the surface for fluoride is much lower, limiting the practical applications of AA. Moreover, it has been reported that alumina begins to leach aluminium and its fluoride complexes below $\mathrm{pH} 6$ and poses severe threats to human health, as aluminium and its fluoride complexes are thought to cause Alzheimer's disease and other health complications (George et al., 2009). Recent attempts to increase the uptake capacity of AA with manganese/manganese oxides (Tripathy and Raichur, 2008; Teng et al., 2009; Alemu et al., 2014), magnesium (Maliyekkal et al., 2008), and iron hydroxide/AA mixtures (Biswas et al., 2007) appear to have been successful, but the mechanisms are unknown.

Adsorbent bed regeneration is an important operation which strongly influences the economical performance of adsorption processes. Any innovative technique that can reduce the cost of the regeneration operation will contribute to making column bed adsorption more efficient and more attractive (Lounici et al., 2001). Several regeneration methods for an activated alumina column saturated with fluoride ions have been reported in the literature (Barbier and Mazaunie, 1984; Schoeman, 2009). These techniques noted that, as a cleaning product, caustic soda was more efficient than other products such as aluminium sulphate, sulphuric acid and aluminate (Barbier and Mazaunie, 1984). Schoeman (2009) regenerated AA by flushing with a solution of $1 \%$ sodium hydroxide, which removes fluoride from the alumina surface. This procedure was followed by flushing with acid to re-establish a positive charge on the surface of the alumina. Subsequent water washing was carried out to raise the $\mathrm{pH}$ to 7 , followed by oven drying. There was a marginal decrease in the adsorption capacity after each regeneration cycle. A loss of $5 \%$ in adsorption capacity of AA was observed after 5 cycles. The following reactions take place in the adsorption regeneration/reactivation cycle of activated alumina (Ghorai and Pant, 2004):

$$
\begin{aligned}
& \mathrm{AlF}+\mathrm{OH}^{-} \rightarrow \mathrm{AlOH}+\mathrm{F}^{-} \\
& \mathrm{AlOH}+\mathrm{H}_{2} \mathrm{SO}_{4} \rightarrow \mathrm{AlHSO}_{4}+\mathrm{HOH}
\end{aligned}
$$

The use of a locally-produced aluminium sulphate and lime combination to precipitate fluoride (the Nalgonda Technique) has been tested in Ethiopia (Feleke and Bekele, 2000). However, based on operational experiences at community scale, the Nalgonda Technique cannot remove sufficient fluoride from water containing fluoride concentrations higher than $10 \mathrm{mg} / \ell$, and requires skilled manpower for operation (Feleke and Bekele, 2000). Imported activated alumina has been used as a filter material to remove fluoride in the Wonji-Shoa and Methara Sugar Estates since 1962, but none of the plants is functional at present (Moges et al., 1996; Feleke and Bekele, 2000), which is attributed to the high running costs and shortage of chemical supply. A local non-governmental organization (NGO) called Oromo Self Help Organization (OSHO) field-tested bone char technology both at household and community scale in rural villages of Ethiopia (Johnson et al., 2011). Although, charring of bones removes organic matter and greatly increases the specific surface area and fluoride adsorption capacity on the bone hydroxyapatite (Christoffersen et al., 1991; Larsen et al., 1994), religious and cultural beliefs may render cow bone char undesirable in certain regions, including Ethiopia.

Moreover, adsorption of fluoride by different adsorbents such as fired clay chips (Moges et al., 1996), waste residue from alum-manufacturing processes (Nigussie et al., 2007), untreated hydrated alumina (UHA) and thermally-treated hydrated alumina (THA) obtained from hydrolysis of locallymanufactured aluminium sulphate (Shimelis et al., 2006), aluminium oxide-manganese oxide composite material (Alemu et al., 2014), nanoscale aluminium oxide hydroxide (AlOOH) (Adeno et al., 2014) and natural zeolite (Gómez-Hortigüela et al., 2013), were among several attempts which have been made in Ethiopia for defluoridation of drinking water.

Recently, the properties and fluoride-adsorption capacity of an aluminium hydroxide-based (AO) adsorbent has been investigated (Mulugeta et al., 2014). Depending on the conditions of precipitation and thermal treatment, the resultant metal oxides exhibit substantial differences, not only in specific surface area and pore size distribution but also in the surface properties. Surface acidity and surface site concentration were estimated by acid-base titration (Dzombak and Morel, 1990; Stumm, 1992; Goldberg et al., 1996). The results from these titrations indicated that the acidity of $\mathrm{AO}$ was greater than its surface site concentration, and thus the acidity is responsible for increasing the fluoride adsorption capacity of AO. This is because the concentration of both protonated surface sites and acid sites, which served as fluoride binding sites, increased significantly with decreasing $\mathrm{pH}$. The results from minicolumn experiments with AO (10 eBV/day, $20 \mathrm{mg} / \ell$ fluoride, $\mathrm{pH} 8 \pm 0.2,10 \mathrm{mM} \mathrm{NaHCO}_{3}, 5.89 \times 10^{-3} \mathrm{~g} / \ell$ of $\mathrm{CO}_{2}$ ), showed that the adsorption capacity of $\mathrm{AO}$ was $9.0 \mathrm{mg} \mathrm{F} / \mathrm{g}$. Moreover, the use of a post-treatment column containing calcite $\left(\mathrm{CaCO}_{3}\right)$ neutralised $\mathrm{pH}$ and controlled both aluminium and sulphate concentrations in the treated water. This approach enabled us to directly use an acid adsorbent while maintaining a high fluoride adsorption capacity. The results encouraged us to test the technology in rural communities of the Ethiopian Rift Valley.

We particularly wanted to compare the AO material to other aluminium hydroxide-based adsorbents, namely, AA and pseudoboehmite (PB), in terms of solubility, uptake capacity and regeneration potential. Depending on the conditions of precipitation and thermal treatment, resulting metal oxides exhibit substantial differences not only in magnitudes of the specific surface area and pore size distribution but also in the surface properties. The objectives of the present work were to: (i) explore the adsorption capacity of the AO adsorbent as a function of $\mathrm{OH}: \mathrm{Al}$ synthesis ratio, (ii) examine the solubility of AO, (iii) compare the fluoride removal and regeneration performance of $\mathrm{AO}$ with other aluminium hydroxide-based adsorbents, and (iv) demonstrate the performance of a high-capacity AO adsorbent in a rural community of the Ethiopian Rift Valley, where groundwaters are highly enriched with fluoride.

\section{MATERIALS AND METHODS}

\section{Adsorbents}

The different forms of $\mathrm{AO}$, aluminium hydro(oxide), were prepared by adding $\mathrm{NaOH}(1.7$ to $2.8 \mathrm{M})$ to $100 \mathrm{~g}$ of $\mathrm{Al}_{2}\left(\mathrm{SO}_{4}\right)_{3} \cdot 14$ $\mathrm{H}_{2} \mathrm{O}$ in $500 \mathrm{m \ell}$ deionised water at the flow rate of approximately $9.1 \mathrm{ml} / \mathrm{min}$ with vigorous stirring $(650 \mathrm{r} / \mathrm{min})$. The amount of $\mathrm{NaOH}$ was adjusted to give $\mathrm{OH}: \mathrm{Al}$ ratios in the final suspension as 2.0, 2.2, 2.5, 2.7, 3.0 and 3.3. The precipitates were filtered, washed with deionised water, dried and heated at $300^{\circ} \mathrm{C}$ in a furnace (Carbolite, ELF Model, UK) for $1 \mathrm{~h}$. The AO which was produced at $2.7 \mathrm{OH}$ :Al ratio $\left(\mathrm{AO}_{2.7}\right)$ was selected for further studies in the present work, due to its fluoride removal performance and surface properties. 
Activated alumina (AA) and pseudoboehmite (PB) were obtained from Albemarle Corporation, Germany. The AA (Compalox ${ }^{\mathrm{R}} \mathrm{AN} / \mathrm{V}-812$ ) has been used for catalytic and adsorptive applications. It has high porosity, large pore volume, high specific surface area $\left(>250 \mathrm{~m}^{2} / \mathrm{g}\right)$, high crushing strength, and high adsorptive capacity for ions such as fluoride, chloride, phosphate, and arsenate. Granular activated alumina is thermally formed from boehmite, AlOOH (Weingartner et al., 1978). Pseudoboehmite has also been widely used in the manufacturing of catalysts, due to its relatively large surface area $\left(300 \mathrm{~m}^{2} / \mathrm{g}\right)$, porosity, crushing strength and thermal stability (Beiding et al., 1973).

\section{Batch experiments}

Batch tests were conducted to characterise $\mathrm{AO}$ produced at different $\mathrm{OH}: \mathrm{Al}$ ratios. The adsorption capacity of each product was determined by mixing $1.6 \mathrm{~g} / \ell$ of the adsorbent in $20 \mathrm{mg} / \ell$ fluoride-containing deionised water in a $250 \mathrm{~m} \ell$ flask. These mixtures were allowed to equilibrate for $60 \mathrm{~min}$ under continuous mixing conditions at room temperature $\left(25^{\circ} \mathrm{C}\right)$ in the thermostatic cabinet. The optimum dose $(1.6 \mathrm{~g} / \ell)$ and contact time (60 $\mathrm{min}$ ) were selected based on the previous study (Shimelis et al., 2006).

\section{Elemental composition analysis}

The aluminium hydroxide-based adsorbents $(0.1 \mathrm{~g})$ were digested in a microwave digester in a 3:1 mixture $(4 \mathrm{ml})$ of $30 \%$ $\mathrm{HCl}$ and $65 \% \mathrm{HNO}_{3}$ for $80 \mathrm{~min}$ and then diluted to $100 \mathrm{m \ell}$ using deionised water (EPA, 2007). The elemental composition was determined by ICP-MS (Agilent 7500CX, USA) and sulphate was determined by ion chromatography (Metrohm 761, Switzerland).

\section{Fluoride analysis}

A fluoride stock solution (1 $000 \mathrm{mg} / \mathrm{\ell})$ was prepared from 99.0\% NaF (Merck, Germany) in deionised water. Standards and samples were prepared by appropriate dilution of the stock solution. The fluoride concentration was measured with a $\mathrm{pH}$ meter (713 Metrohm, Switzerland) equipped with ion-selective fluoride electrode (Metrohm 6.0502.150, Switzerland) and Ag/ $\mathrm{AgCl}$ reference electrode (6.0726.100 Metrohm, Switzerland). Analyses were performed on equal-volume mixtures of sample and total ionic strength adjustment buffer (TISAB). Total ionic strength adjustment buffer (TISAB) solution was prepared by following a recommended procedure (Bailey, 1980), except that CDTA (trans-1,2-diamineciclohexane-tetracetic acid) was replaced by EDTA.

\section{Acid-base titrations}

Acid-base titrations for aluminium hydroxide-based adsorbents ( $\mathrm{AO}, \mathrm{AA}$ and $\mathrm{PB}$ ) were carried out at $\mathrm{pH}$ values between 5 and 10 with $0.5 \mathrm{~g}$ adsorbent in electrolyte solution $(0.1 \mathrm{M} \mathrm{NaCl}$, $50 \mathrm{ml}$ ) under $\mathrm{CO}_{2}$-free conditions, at a constant temperature of $25^{\circ} \mathrm{C}$. The titrants used were $0.1 \mathrm{M} \mathrm{NaOH}$ and $0.1 \mathrm{M} \mathrm{HCl}$. Before titration, the samples were equilibrated with the electrolyte solution for an hour, gently stirring under a continuous stream of purified nitrogen with $100 \%$ humidity (Yang et al., 2007; Mulugeta et al., 2014). The adsorbent was then rapidly titrated (60 s per titration step) to $\mathrm{pH} 10$. The suspension was then equilibrated for $10 \mathrm{~min}$ prior to centrifugation to separate the solid from the solution. Both were then back-titrated separately to a $\mathrm{pH}$ of around 5 . After $10 \mathrm{~min}$, the procedure was repeated. The titration was performed by Dosimat $(665$ Metrohm, Switzerland), with a combined $\mathrm{pH}$ glass electrode (WTW Inolab pH/ION Level 2, Germany) calibrated using Gran titration method (Gran, 1952). This experiment was performed in duplicate.

\section{Aluminium solubility}

The AO powder was suspended in deionised water containing an inert electrolyte $(0.1 \mathrm{M} \mathrm{NaCl})$ in closed plastic bottles with an oxide/water ratio of $1 \mathrm{~g} / 100 \mathrm{~m} \ell$ for 6 days under continuous stirring at room temperature $\left(25^{\circ} \mathrm{C}\right)$ (Carrier et al., 2007). The $\mathrm{pH}$ was adjusted from 3 to 11 by addition of either $0.1 \mathrm{M} \mathrm{HCl}$ or $\mathrm{NaOH}$ throughout the experiments. The aluminium content was compared to standard aluminium hydroxide solubilities determined using the ChemEQL software (Muller, 1992).

\section{NMR analysis}

High resolution ${ }^{27} \mathrm{Al}$ magic angle spinning nuclear magnetic resonance $\left({ }^{27} \mathrm{Al}\right.$ MAS NMR) spectra of $\mathrm{AO}, \mathrm{AA}$ and $\mathrm{PB}$ were recorded, to analyse the coordination geometry of the solid $\mathrm{Al}$ species formed, on a Bruker AVANCE-400 spectrometer operating at $104.3 \mathrm{MHz}$ and equipped with a high-speed MAS probe head $(2.5 \mathrm{~mm}$ zirconia rotor spinning up to $35 \mathrm{kHz}$ ). A relaxation delay of $1 \mathrm{~s}$ and pulse length of $0.3 \mu$ s were used to collect the ${ }^{27} \mathrm{Al}$ MAS NMR spectrum. Chemical shifts are referenced with respect to an external $\mathrm{Al}\left(\mathrm{NO}_{3}\right)_{3}$ aqueous solution, i.e., the resonance of $\mathrm{Al}\left(\mathrm{H}_{2} \mathrm{O}\right)_{6}{ }^{3+}$ was set to $0 \mathrm{ppm}$.

\section{Column experiments}

To investigate the fluoride removal performance of $\mathrm{AO}, \mathrm{AA}$ and PB under continuous operation, 3 columns, each with length $11 \mathrm{~cm}$ and internal diameter $3.4 \mathrm{~cm}$, were packed with the adsorbents. The amount of $\mathrm{AO}, \mathrm{AA}$ and $\mathrm{PB}$ packed in these columns was 31, 100, and $41 \mathrm{~g}$, respectively. The peristaltic pump (ISMATEC, REGIO-CPF Analog, Switzerland) was used to introduce a synthetic buffered solution $\left(10 \mathrm{mM} \mathrm{NaHCO}_{3}\right.$ and $5.89 \times 10^{-3} \mathrm{~g} / \ell$ of $\mathrm{CO}_{2}$ ) containing $20 \mathrm{mg} / \ell$ fluoride at a controlled flow rate of 10 empty bed volumes per day in the upflow mode through the columns. The effluent from all of the columns was collected at defined time intervals and examined for $\mathrm{pH}$, aluminium, sodium, sulphate and fluoride concentration. The regeneration experiments were initiated when the fluoride concentration in the effluent exceeded $1.5 \mathrm{mg} / \ell$ and conducted using a sodium hydroxide solution. $0.01 \mathrm{M} \mathrm{NaOH}$ was used to regenerate $\mathrm{AO}$ and $0.25 \mathrm{M} \mathrm{NaOH}$ for $\mathrm{AA}$ and $\mathrm{PB}$ at a flow rate of $8.3 \mathrm{ml} / \mathrm{min}$ for $60 \mathrm{~min}$. For all cases, rinsing and neutralisation $\left(0.02 \mathrm{M} \mathrm{H}_{2} \mathrm{SO}_{4}\right)$ steps were followed with flow rate of $8.3 \mathrm{ml} / \mathrm{min}(60 \mathrm{~min})$ and $16.7 \mathrm{ml} / \mathrm{min}(90 \mathrm{~min})$, respectively (Schoeman, 2009). Multiple adsorption/desorption cycles were also executed for up to 3 cycles.

\section{Field implementation}

The community AO defluoridation plant was designed, constructed and commissioned in Tsutchigragona, Oromya Regional State, Ethiopia (Latitude: $8^{\circ} 10^{\prime} 1.19^{\prime \prime} \mathrm{N}$; Longitude: $38^{\circ} 53^{\prime} 12.67^{\prime \prime}$ E) in July, 2011. The AO community defluoridation pilot plant was run twice by replacing the spent media with fresh media in the second round in May, 2012. The AO adsorbent was prepared at a pilot scale, based on scaling up of the 


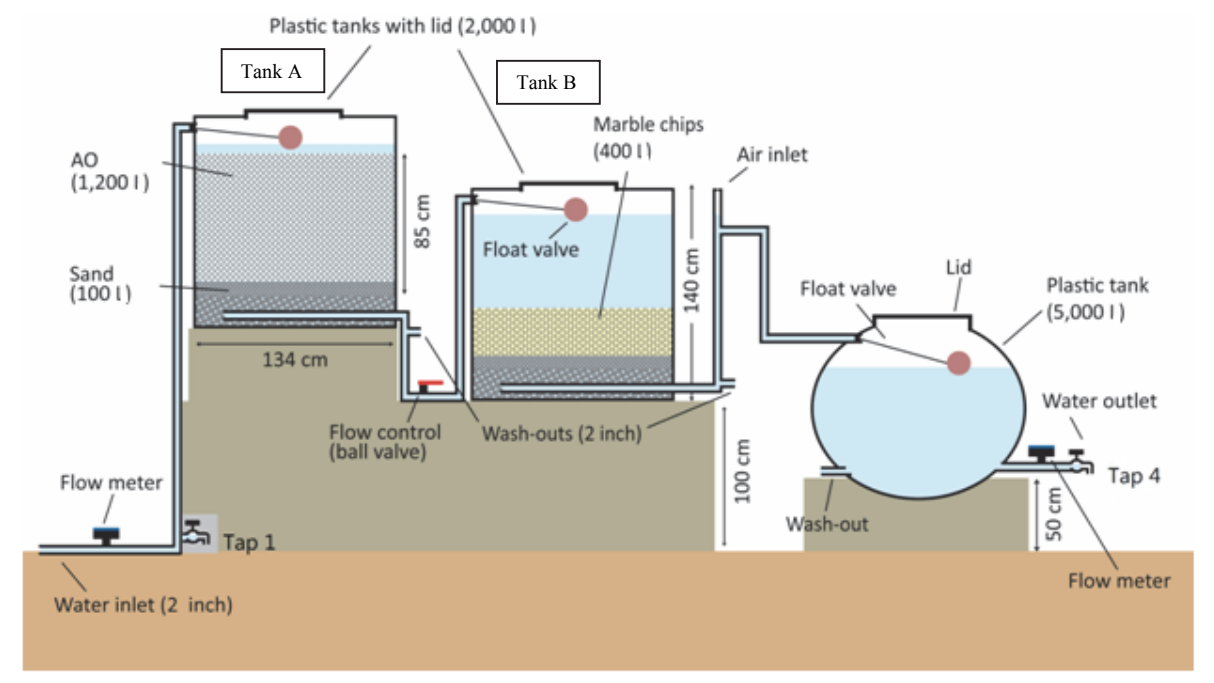

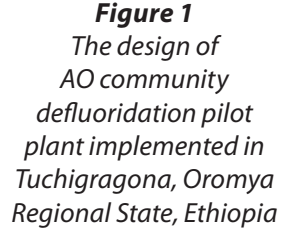

laboratory synthesis scheme. A schematic of the community defluoridation plant is presented in Fig. 1.

The field test was undertaken based on laboratory results. The principal variables which affect the performance of the adsorbent were flow rate, ions, $\mathrm{pH}$ of raw water, and potential leaching of aluminium and sulphate from the adsorbent during continuous operation. The groundwater is pumped by a windmill. Groundwater with fluoride concentration in the range of 8 to $10 \mathrm{mg} / \ell$ was treated by a packed bed of $\mathrm{AO}$ media (Tank A), and through a calcite bed, to control treated water $\mathrm{pH}$ and potential leaching of aluminium (Tank B). The flow rate was adjusted to about $3 \mathrm{l} / \mathrm{min}$ by using a flow control valve, installed between Tank A and Tank B. During the first day of operation, Tank A was washed until the electrical conductivity of the water was less than $1500 \mu \mathrm{s} / \mathrm{cm}$.

The performance of the community defluoridation plant was monitored by collecting influent and effluent water samples once a week. Temperature, $\mathrm{pH}, \mathrm{EC}$ and turbidity of the raw water and treated water, before and after the calcite bed, and finally after the treated water storage tank, were measured onsite. Water meter readings were also recorded during which samples were taken. However, fluoride, aluminium, sulphate and other parameters were measured offsite.

\section{RESULTS AND DISCUSSION}

\section{Optimisation of the synthesis of $\mathrm{AO}$ adsorbent}

The yield, elemental composition and fluoride adsorption capacity are listed in Table 1 as a function of the $\mathrm{OH}$ :Al reactant ratio. The fluoride uptake is also shown with mineral and surface acidity in Fig. 2. A maximum yield is obtained at $\mathrm{OH}: \mathrm{Al}$ ratios of 2.5 to 3.0. In acidic production conditions $\left(\mathrm{AO}_{2.0}, \mathrm{AO}_{2.2}\right)$ and strongly alkaline conditions $\left(\mathrm{AO}_{33}\right)$ the aluminium ions become quite soluble, either as $\mathrm{Al}^{3+}$ or $\mathrm{Al}(\mathrm{OH})_{4}^{-}$, respectively. The fluoride-uptake batch test also shows that the lowest fluoride uptake is found under alkaline conditions. The uptake is higher under acidic conditions, as reported in the literature (Mulugeta et al., 2014). However, the highest fluoride uptake coincides with the largest yields under slightly acidic to neutral $\mathrm{pH}$ conditions $\left(\mathrm{AO}_{2.5}, \mathrm{AO}_{2.7}\right)$; thus an $\mathrm{AO}$ product with $\mathrm{OH}$ : $\mathrm{Al}$ ratios under 3 appears to be optimal for fluoride removal. An AO with an $\mathrm{OH}: \mathrm{Al}$ ratio of 2.7 was selected for further experimentation.

\section{Surface acidity of aluminium hydroxide-based adsorbents}

The surface acidity and surface site concentrations of AO, AA and $\mathrm{PB}$ determined using acid-base titration are shown in Table 2. The surface area of $A A$ and $P B$ is 5 to 8 times larger than that of $\mathrm{AO}$, although, as can be seen in Fig. 5, the uptake capacity of $\mathrm{AO}$ is larger than that of the other two products. Under the experimental conditions used, the uptake capacity for $1.5 \mathrm{mg} / \ell$ fluoride for $\mathrm{AO}$ was almost 5 times that of $\mathrm{AA}$ and $\mathrm{PB}$. One reason for this observation is the larger available surface site concentration. The acidity of the AO product is another likely contributing factor to the relatively large adsorption capacity.

\section{Aluminium solubility of AO}

The measured dissolved concentration of aluminium in water equilibrated with $\mathrm{AO}$ is compared with that of amorphous

\begin{tabular}{|c|c|c|c|c|c|c|c|c|}
\hline & & omposit & $\mathrm{n}$ of $A O \mathrm{~s}$ & $\begin{array}{c}\text { TABLE } 1 \\
\text { nthesised a }\end{array}$ & differen & H:Al rat & & \\
\hline Sample & $\mathrm{OH}: \mathrm{Al}$ & & Yield(g) & Adsorption & & lemental & mpositior & \\
\hline & & $\begin{array}{c}\mathrm{pH} \text { after } \\
\text { mixing }\end{array}$ & & $\begin{array}{c}\text { capacity } \\
(\mathrm{mg} / \mathrm{g})\end{array}$ & $\begin{array}{c}\mathrm{Al} \\
\mathrm{mmol} / \mathrm{g}\end{array}$ & $\begin{array}{c}\mathrm{SO}_{4}^{2-} \\
\mathrm{mmol} / \mathrm{g}\end{array}$ & $\begin{array}{c}\mathrm{Na} \\
\mathrm{mmol} / \mathrm{g}\end{array}$ & $\begin{array}{c}\mathrm{Fe} \\
\mathrm{mmol} / \mathrm{g}\end{array}$ \\
\hline $\mathrm{AO}_{2.0}$ & 2.0 & 4.0 & 30.7 & 7.60 & 5.10 & 4.2 & 0.28 & 0.08 \\
\hline $\mathrm{AO}_{2.2}$ & 2.2 & 4.1 & 36.4 & 7.91 & 7.50 & 4.1 & 0.32 & 0.12 \\
\hline $\mathrm{AO}_{2.5}$ & 2.5 & 6.5 & 49.0 & 12.2 & 10.7 & 3.2 & 0.00 & 0.15 \\
\hline $\mathrm{AO}_{2.7}$ & 2.7 & 7.1 & 45.7 & 12.0 & 10.9 & 2.2 & 0.00 & 0.15 \\
\hline $\mathrm{AO}_{3.0}$ & 3.0 & 8.9 & 47.2 & 3.94 & 13.7 & 0.3 & 0.01 & 0.19 \\
\hline $\mathrm{AO}_{3.3}$ & 3.3 & 10.7 & 32.9 & 2.81 & 15.7 & 0.1 & 0.19 & 0.28 \\
\hline
\end{tabular}




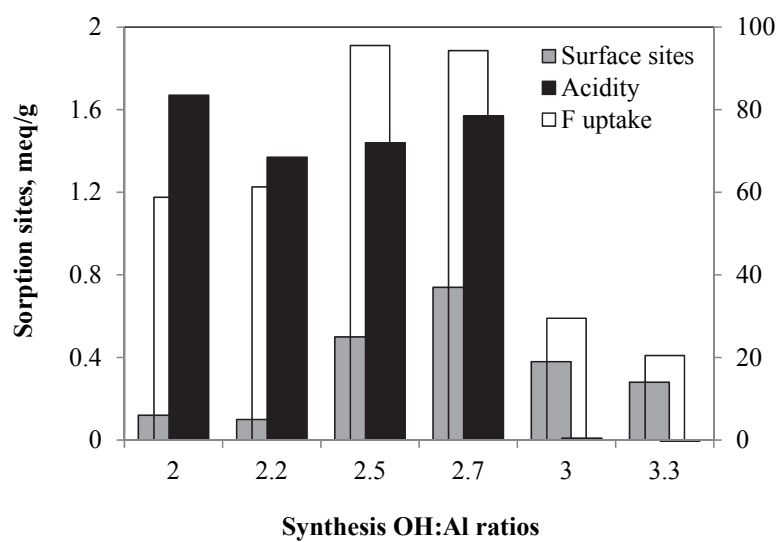

Figure 2

Fluoride uptake and binding sites as a function of OH:Al synthesis ratios

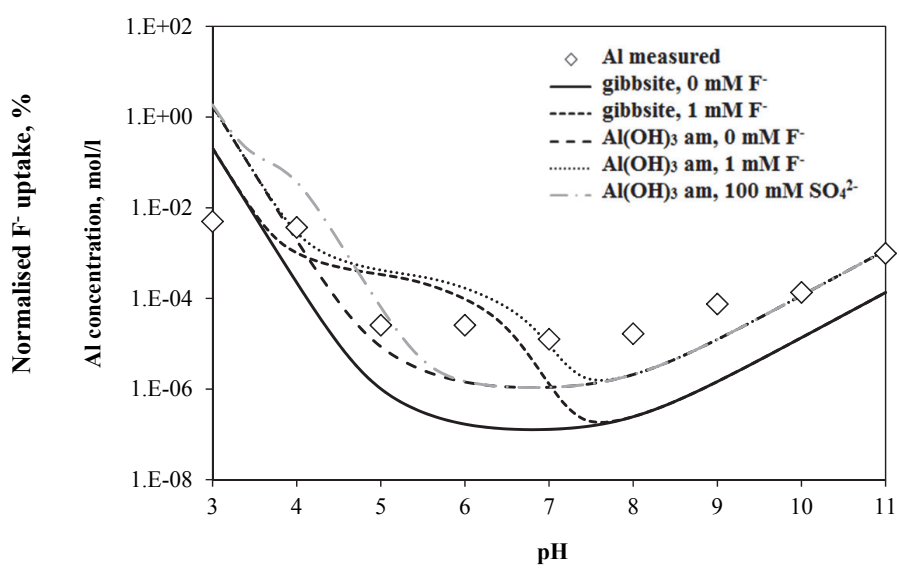

Figure 3

Solubility profiles. Concentration of Al(III) in solution (mol/e) as a function of $\mathrm{pH}$ for $\mathrm{AO}$ (measured) compared to model calculations for gibbsite and amorphous aluminium hydroxide in the absence and presence of $1 \mathrm{mM}$ fluoride for an ionic strength of $0.01 \mathrm{M},\left[\mathrm{CO}_{3 \text { too }}\right]=1 \mathrm{mM}$ and $\left[\mathrm{Ca}_{\text {to }}\right]=0.1 \mathrm{mM}$

\begin{tabular}{|c|c|c|c|c|c|c|c|c|}
\hline \multicolumn{9}{|c|}{$\begin{array}{c}\text { TABLE } 2 \\
\text { Surface area, acidity, surface site concentration, and elen }\end{array}$} \\
\hline \multirow[t]{2}{*}{ Sample } & \multirow{2}{*}{$\begin{array}{c}\text { Surface } \\
\text { area } \\
\left(\mathrm{m}^{2} / \mathrm{g}\right)\end{array}$} & \multirow{2}{*}{$\begin{array}{l}\text { Acidity } \\
\text { (meq/g) }\end{array}$} & \multirow{2}{*}{$\begin{array}{l}\text { Surface } \\
\text { site conc. } \\
\text { (meq/g) }\end{array}$} & \multicolumn{4}{|c|}{ Elemental composition $\%$} & \multirow[t]{2}{*}{ Tota } \\
\hline & & & & $\mathrm{Al}_{2} \mathrm{O}_{3}$ & $\mathrm{Na}_{2} \mathrm{O}$ & $\mathrm{SO}_{4}$ & $\mathrm{Fe}_{2} \mathrm{O}_{3}$ & \\
\hline Aluminium hydro(oxide) (AO), Ethiopia & 37.7 & 1.57 & 0.74 & 78.3 & 0.01 & 19.4 & 2.20 & 99.9 \\
\hline $\begin{array}{l}\text { Activated alumina (AA) }\left(\text { Compalox }^{\mathrm{R}}\right. \\
\text { AN/V-812), Germany }\end{array}$ & 250 & -0.24 & 0.20 & 90.0 & 0.35 & - & 0.01 & 90.1 \\
\hline Pseudoboehmite (PBE), Germany & 300 & -0.23 & 0.39 & 95.0 & 0.1 & 0.2 & 0.02 & 95.3 \\
\hline
\end{tabular}

aluminium hydroxide and gibbsite, as a function of $\mathrm{pH}$, in Fig. 3. The results indicate that the solubility of $\mathrm{AO}$ resembles that of amorphous aluminium hydroxide rather than gibbsite. Gibbsite was chosen, because it is the most thermodynamically stable phase in conditions ranging from acidic to neutral, in contact with water, which is also present on the hydrated surface of AA (Karamilidis and Dzombak, 2010). The solubility of $\mathrm{AO}$ is slightly higher than that of amorphous aluminium hydroxide. There may be several reasons for this. Firstly, it is possible that sulphate complexes with $\mathrm{Al}^{3+}$, though the effect would be greater at low $\mathrm{pH}$; secondly there may be some metastable $\mathrm{Al}-\mathrm{OH}-\mathrm{SO}_{4}$ phases and, lastly, though great care was taken, there may be some contamination at concentrations below $10 \mu \mathrm{M}$.

\section{Aluminium coordination in fresh and used adsorbents}

Aluminium NMR chemical shifts are directly related to the coordination number of the Al(III) ion (MacKenzie and Smith, 2002). Chemical shifts for octahedral Al(III) units appear between 10 and $20 \mathrm{ppm}$, while tetrahedral $\mathrm{Al}(\mathrm{III})$ centres exhibit peaks between 50 and $80 \mathrm{ppm}$. Resonances for 5-coordinate $\mathrm{Al}(\mathrm{III})$ species, while less common, are typically observed in the range of $25-35 \mathrm{ppm}$. Figure 4 shows the ${ }^{27} \mathrm{Al} \mathrm{NMR} \mathrm{spectrum} \mathrm{of} \mathrm{AO}, \mathrm{AA}$ and $\mathrm{PB}$, before and after $10 \mathrm{mg} / \mathrm{g}$ fluoride adsorption. The spectra of AO displayed one main signal at $\delta \sim 4.64$ and $5.01 \mathrm{ppm}$, before and after fluoride adsorption, respectively. AO also showed 2 satellite signal peaks at $\delta \sim 31.5$ and $63.5 \mathrm{ppm}$ (before $\mathrm{F}^{-}$adsorption) and $\delta \sim 34.5$ and 67.0 ppm (after $\mathrm{F}^{-}$adsorption). These three signals (for the two cases) were indicative of 6-, 5- and 4-coordinate aluminium species, respectively (Bagshaw and Pinnaviaia,

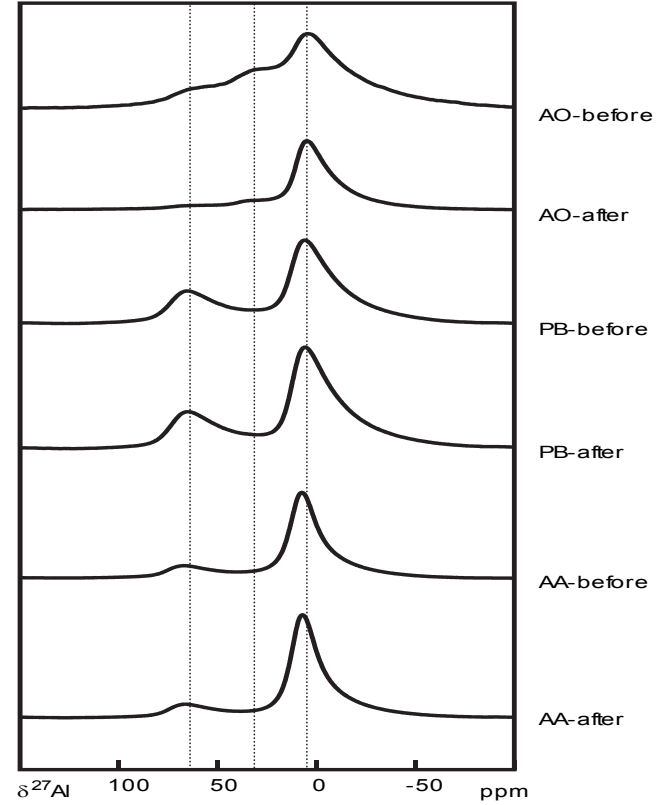

Figure 4

${ }^{27} \mathrm{Al}$ MAS NMR spectra recorded at room temperature for $A O$, psuedoboehmite (PB) and activated alumina ( $A A)$; before and after $(10 \mathrm{mg} / \mathrm{g})$ fluoride adsorption

1996; Urretavizcya et al., 1998). In the spectra of AA and $\mathrm{PB}$, only 2 signals were observed. In the spectra of $\mathrm{AA}$, the signal at $\delta \sim 7.43$ and $66.9 \mathrm{ppm}$ (before $\mathrm{F}^{-}$adsorption) and at $\delta \sim 7.31$ and $66.6 \mathrm{ppm}$ (after $\mathrm{F}^{-}$adsorption), indicates that 

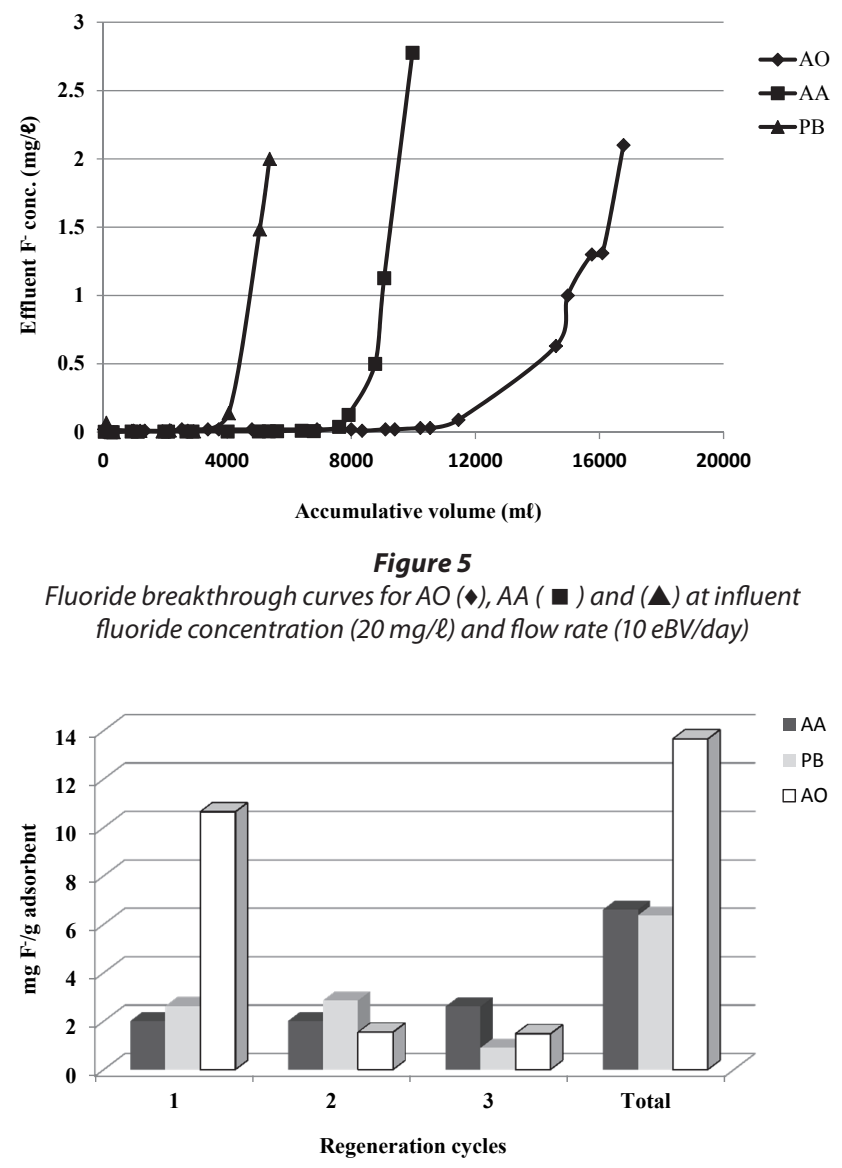

Figure 6

Adsorption capacities of $A O, A A$ and $P B$ after repeated regeneration

the 6- and 4-coordinated $\mathrm{Al}$ species were observed, respectively. In the spectra of $\mathrm{PB}$ a signal at $\delta \sim 6.11$ and $65.4 \mathrm{ppm}$ (before $\mathrm{F}^{-}$adsorption) and $\mathrm{PB}$ at $\delta \sim 5.93$ and $65.2 \mathrm{ppm}$ (after $\mathrm{F}^{-}$adsorption), also indicates that the 6- and 4-coordinated $\mathrm{Al}$ species were observed, respectively. The main signal assigned to 6-coordinated $\mathrm{Al}$ species of $\mathrm{AO}$ after adsorption of fluoride shifted to $\delta=5.01 \mathrm{ppm}$. Moreover, the resonance signal of AO exhibited a much broader distribution than that of AA and $\mathrm{PB}$, implying low uniformity in the chemical environment of $\mathrm{Al}$ species in the well-defined, regular shaped $\mathrm{AA}$ or $\mathrm{PB}$ adsorbents (Robert et al., 1991).

The features relevant to tetrahedral Al ( $60 \mathrm{ppm})$, pentahedral $\mathrm{Al}(\sim 30 \mathrm{ppm})$, and octahedral $\mathrm{Al}(\sim 0 \mathrm{ppm})$ (Stebbins et al., 2000) revealed by the ${ }^{27} \mathrm{Al}$ MAS NMR spectra of AO, as for amorphous $\mathrm{Al}_{2} \mathrm{O}_{3}$ thin films, are not consistent with the NMR patterns for crystalline alumina polymorphs (Kim et al., 2007). The 5- and 4-coordinations shown in AO are characteristic of amorphous aluminium hydroxide (Sung et al., 2010).

The change in spectrum of $\mathrm{AO}$ after fluoride addition indicated a change in structure. According to the compilation of Mackenzie and Smith (2002), octahedral coordination of aluminium predominates in hydrous oxides, while some tetrahedral coordination is observed in aluminium oxides. The decrease in $\mathrm{AO}$ of 4 - and 5-coordination indicates a transition to a hydrous aluminium oxide. The cause of this change may be maturation by suspension in water, exchange of hydroxyl and/or sulphate ions for fluoride, or both.

\section{Performance of aluminium hydroxide-based adsorbents in packed bed columns}

The breakthrough curves for the column packed with AO, $\mathrm{AA}$ and $\mathrm{PB}$ were determined by plotting the effluent fluoride concentration against the effluent throughput volume (Fig. 5). In all of the columns, fluoride removal was initially high, but decreased progressively over time. A $\mathrm{pH}$ variation of $7.0 \pm 1.0$ (AO), $8.0 \pm 0.9$ (AA) and $8.0 \pm 1.0(\mathrm{~PB})$ was observed in the effluent from all of the columns and for the influent solution a $\mathrm{pH}$ of $8 \pm 0.3$ was recorded. The adsorption capacity for each adsorbent was calculated as 10.6, 1.9 and $2.4 \mathrm{mg} \mathrm{F} / \mathrm{g}$ for $\mathrm{AO}$, $\mathrm{AA}$ and $\mathrm{PB}$, respectively. Thus, the adsorption capacity of $\mathrm{AO}$ is about 5 times higher than for both AA and PB.

The release of aluminium and sulphate from the aluminium hydroxide-based adsorbents is an issue of concern for fluoride removal from water. The release of aluminium from AA (0.5$2.3 \mathrm{mg} / \ell)$ and $\mathrm{PB}(0.5-1.2 \mathrm{mg} / \ell)$, until fluoride breakthrough concentration $(1.5 \mathrm{mg} / \ell)$, was higher than $0.2 \mathrm{mg} / \ell$, which is the USEPA guideline for $\mathrm{Al}$ in drinking water (USEPA, 2008). However, the aluminium concentration in the effluent from $\mathrm{AO}$ was below $0.2 \mathrm{mg} / \ell$. The sulphate concentration in the effluent was also examined for $\mathrm{AA}$ and $\mathrm{PB}$, which was found to be $<600$ $\mathrm{mg} / \ell$ and $<350 \mathrm{mg} / \ell$, respectively, until fluoride breakthrough concentration. However, for $\mathrm{AO}$ the sulphate concentration was high (> $2000 \mathrm{mg} / \mathrm{\ell})$, as compared with the WHO test threshold level (WHO, 2011), during the first flash $(<10 \mathrm{eBV})$, but reduced quickly to a level below $550 \mathrm{mg} / \ell$.

The uptake capacity to $1.5 \mathrm{mg} / \ell \mathrm{F}$ of the three adsorbents was determined after regeneration (Fig. 6). It was found that for $\mathrm{AO}$ there was a drastic change in capacity from 10.6 to $2.0 \mathrm{mg} / \mathrm{g}$ after the first cycle of operation. The $\mathrm{AO}$ adsorbent became unstable when regenerated with $0.01 \mathrm{M} \mathrm{NaOH}$ after 3 cycles and $20 \mathrm{wt} \%$ was lost. The regeneration of AA and PB did not result in the loss of material or capacity for the three cycles of regeneration. However, the total fluoride capacity of $\mathrm{AO}$ was twice that of AA and PB after 3 cycles. Thus the obvious advantage of $\mathrm{AO}$ is initial capacity, but that of AA and $\mathrm{PB}$ is stability and the potential for many regeneration cycles. The advantage of $\mathrm{AO}$ is that a filter could potentially run for a long time without media replacement.

\section{Performance of community-scale AO defluoridation system}

The plant was functional for about 3 months, removing fluoride in the feed water from 8 to $10 \mathrm{mg} / \ell$ to less than 0.1 $\mathrm{mg} / \ell$, until the fluoride content in the treated water exceeded $1.5 \mathrm{mg} / \ell$. The fluoride adsorption capacity determined for the first and second field tests was 1.7 and $2.5 \mathrm{mg} / \mathrm{g}$, respectively. Plant output varied between 81 and $160 \mathrm{~m}^{3}$ to a fluoride breakthrough of $1.5 \mathrm{mg} / \ell$ during the two field tests, respectively. The system is simple to operate and fully accepted by the community (Huber and Mosler, 2012), and is a less energy-intensive process for fluoride removal in rural areas. No significant operational problems and complaints from the beneficiaries were experienced during field operation.

The treated water quality is presented in Table 3 which shows that the $\mathrm{pH}$ of raw water is, on average, 8 , which is mainly because of a high bicarbonate ion concentration. The groundwater in central parts of the Ethiopian Rift Valley is characterised by high bicarbonate content (Mulugeta et al., 2014). This accounts for the reduction in fluoride adsorption 


\begin{tabular}{|c|c|c|}
\hline \multicolumn{3}{|c|}{$\begin{array}{c}\text { TABLE } 3 \\
\text { Average water quality characteristics of groundwater } \\
\text { and treated water before the fluoride concentration } \\
\text { reaches } 2.0 \mathrm{mg} / \ell\end{array}$} \\
\hline Constituents & Raw water (mg/l) & Treated water $(\mathrm{mg} / \mathrm{l})$ \\
\hline Fluoride & $8.1-10.1$ & $0.01-2.18$ \\
\hline Sulphate & $7.1-9.5$ & $69.1-1006$ \\
\hline Chloride & $63.4-67.7$ & $61.9-68.2$ \\
\hline Aluminium & $(4.9-18.2) \times 10^{-3}$ & $(12.8-59.4) \times 10^{-3}$ \\
\hline Sodium & $278-295$ & $283-336$ \\
\hline Iron & $1.77-2.56$ & $1.85-2.62$ \\
\hline Calcium & $29.5-33.1$ & $22.3-71.5$ \\
\hline Silicon & $29.7-30.8$ & $1.7-4.4$ \\
\hline Magnesium & $6.8-7.3$ & $5.9-9.2$ \\
\hline Arsenic & $(1.3-5.1) \times 10^{-3}$ & $(0.2-0.4) \times 10^{-3}$ \\
\hline Uranium & $(1.3-1.8) \times 10^{-3}$ & $(0.1-0.3) \times 10^{-3}$ \\
\hline Selenium & $(2.9-5.1) \times 10^{-3}$ & $(0.1-0.8) \times 10^{-3}$ \\
\hline $\mathrm{pH}$ & $7.84-8.23$ & $6.68-8.30$ \\
\hline $\mathrm{EC}(\mu \mathrm{s} / \mathrm{cm})$ & $1670-1850$ & $1670-2680$ \\
\hline
\end{tabular}

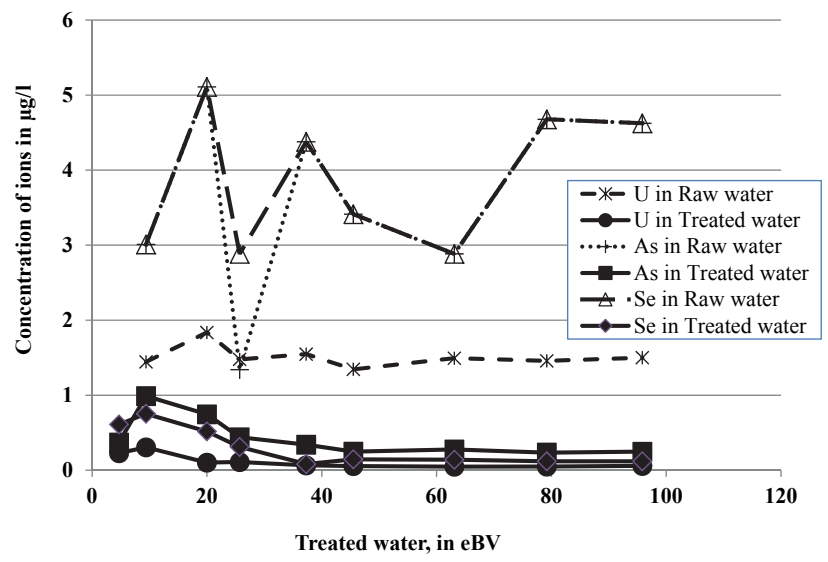

Figure 7

Potential of AO for uptake of arsenic, uranium and selenium

capacity of $\mathrm{AO}$ because $\mathrm{pH}$ increases as $\mathrm{HCO}_{3}{ }^{-}$content increases. It is further important to note that the aluminium concentration in the treated water was higher than for raw water, because $\mathrm{Al}$ is leached from the adsorbent, but the concentration was far less than $0.2 \mathrm{mg} / \ell$ (Table 3 ). As observed from column experiments in the laboratory, the sulphate concentration during the first flush was about $1000 \mathrm{mg} / \ell$; however it was reduced to below $600 \mathrm{mg} / \ell$ after $10 \mathrm{eBV}$ passed through the column. The chloride concentration in the feed and treated water was almost the same, which indicates that the presence of chloride does not affect the removal capacity of AO. However, the silicon concentration diminished from $\sim 30$ to $\sim 3 \mathrm{mg} / \ell$ from the raw to treated water, indicating the adsorption of $S i$ onto $\mathrm{AO}$ with a possible reduction in the fluoride adsorption capacity. It was also observed that the $\mathrm{AO}$ has a potential to remove other contaminants such as arsenic and uranium, and also selenium. Even though the concentrations of these contaminants in the groundwater were below the WHO guideline values (WHO, 2011), the adsorbent reduced the concentrations far below the initial levels (Fig. 7).

\section{CONCLUSIONS}

This work has shown the possible processes underlying the high fluoride adsorption capacity of $\mathrm{AO}$ and has shown the potential and limitations of AO for fluoride removal in the field. The solubility curve and ${ }^{27} \mathrm{Al}$ NMR spectra for AO are indicative of an amorphous aluminium hydroxide. The AO adsorbent, which was synthesised at an $\mathrm{OH}$ : Al ratio of 2.7, had a very high fluoride removal capacity in the laboratory, approximately 5 times higher than that of $\mathrm{AA}$ and $\mathrm{PB}$. Thus, high surface area and $\mathrm{Al}_{2} \mathrm{O}_{3}$ composition does not ensure better fluoride removal performance for aluminium hydroxide-based adsorbents. The regeneration of $\mathrm{AO}$ with $\mathrm{NaOH}$ resulted in a reduction in adsorption capacity, resulting from the loss of acidity, to the range of $\mathrm{AA}$ and $\mathrm{PB}$, but with lower physical stability. The field tests showed that water filtration with $\mathrm{AO}$ functioned and was accepted by the community. However, the uptake capacity was significantly lower than in the laboratory and there were indications that silicate ions may be adsorbed as well as fluoride. It was also observed that

the $\mathrm{AO}$ has the potential to remove other contaminants such as arsenic, uranium and selenium. We conclude that $\mathrm{AO}$ has the potential for field implementation, but further studies are needed to assess the role of silicate ions and to select the best method for regenerating $\mathrm{AO}$. Also, the release of $\mathrm{Al}$ from the commonly-used AA deserves greater attention in order to ensure the quality of treated water.

\section{ACKNOWLEDGEMENTS}

We would like to thank the Swiss National Science Foundation (SNSF) for financial support and the Swiss Federal Institute of Aquatic Science and Technology (Eawag) for experimental support. We would also like to express our utmost gratitude to the Ethiopian Ministry of Water and Energy (MoWE) and a local non-governmental organization, Oromo Self Help Organization (OSHO), for their technical support. We thank Dr Hofius Henning from Albemarle, Germany, for providing the adsorbents and Dr Daniel Rentsch from Swiss Federal Laboratories for Material Sciences and Technology (EMPA) for undertaking the ${ }^{27} \mathrm{Al}$ NMR analysis. Special thanks go to Eawag staff, Mr Lars Osterwalder, Mr Michael Simmler, Mr Marcel Mathis and Mr Hermann Moench.

\section{REFERENCES}

ADENO F, MULUGETA E, ZEWGE F and CHEBUDE Y (2014) Adsorptive removal of fluoride from water using nanoscale aluminium oxide hydroxide (AlOOH). Bull. Chem. Soc. Ethiop. 28 215-227.

ALEMU S, MULUGETA E, ZEWGE F and CHANDRAVANSHI BS (2014) Water defluoridation by aluminium oxide-manganese oxide composite material. Environ. Technol. 15 1893-1903.

BAILEY PL (1980) Analysis with Ion-Selective Electrodes (3 ${ }^{\text {rd }}$ edn.). Heydon, London. 196 pp.

BAGSHAW SA and PINNAVIAIA TJ (1996) Mesoporous alumina molecular sieves. Angew. Chem. Int. Ed. Engl. 35 1102-1105.

BARBIER JP and MAZOUNIE P (1984) Methods of reducing high fluoride content in drinking water. Fluoride removal methodsfiltration through activated alumina: a recommended technique. Water Supply 2 3-4.

BEIDING WA, EMERSON RB, and WILLIAMS RL (1973) Agglomerating partially dehydrated gel-derived pseudoboehmitic alumina to form strong porous spheres. United States, Kaiser Aluminium and Chemical Corporation (Oakland, CA), Patent No. 3714313. URL: http://www.freepatentsonline.com/3714313.html (Accessed 24 August 2013). 
BISWAS K, SAHA SK and GHOSH UC (2007) Adsorption of fluoride from aqueous solution by a synthetic iron(III)-aluminium(III) mixed oxide. Ind. Eng. Chem. Res. 46 5346-5356.

BREGNHOJ H (1997) Critical sustainability parameters in defluoridation of drinking water. $2^{\text {nd }}$ International Workshop on Fluorosis and Defluoridation of Water, 19-22 November 1997, Nazareth, Ethiopia.

CARRIER X, MARCEAU E, JEAN-FRANÇOIS L and CHE M (2007) Transformations of $\gamma$-alumina in aqueous suspensions; alumina chemical weathering studied as a function of $\mathrm{pH}$. J. Colloid Interf. Sci. 308 429-437.

CHRISTOFFERSEN J, CHRISTOFFERSEN MR, LARSEN R and MOLLER IJ (1991) Regeneration by surface-coating of bone char used for defluoridation of water. Water Res. 25 227-229.

DZOMHAK DA and MOREL FMM (1990) Surface Complexation Modeling: Hydrous Ferric Oxide. Wiley-Interscience, New York.

EPA (ENVIRONMENTAL PROTECTION AGENCY) (2007) Microwave assisted acid digestion of sediments, sludges, soils, and oils. EPA Method 3051A. USEPA, Washington, D.C.

FELEKE $Z$ and BEKELE A (2000) Alem Tena Catholic Church Defluoridation Pilot Study. A report submitted to the Ethiopian Science and Technology Commission, Addis Ababa, Ethiopia, $50 \mathrm{pp}$.

GEORGE S, PANDIT P, GUPTA AB, and AGARWAL M (2009) Modeling and Simulation Studies for Aluminium-Fluoride Interactions in Nalgonda Defluoridation Process. Chemical Products and Process Modeling, Vol 4, The Berkeley Electronic Press, Berkeley. $27 \mathrm{pp}$.

GHORAI S and PANT KK (2004) Investigations on the column performance of fluoride adsorption by activated alumina in a fixed-bed. J. Chem. Eng. 98 165-173.

GHORAI S and PANT KK (2005) Equilibrium, kinetics and breakthrough studies for adsorption of fluoride on activated alumina. Sep. Purif. Technol. 42 265-271.

GOLDBERG S, DAVIS JA and HEM JD (1996) The surface chemistry of aluminium oxides and hydroxides. In: Sposito G (ed.) The Environmental Chemistry of Aluminium (2 ${ }^{\text {nd }}$ edn.) Vol 27. Lewis Publishers, Boca Raton. 33 pp.

GÓMEZ-HORTIGÜELA L, PÉREZ-PARIENTE J, GARCÍA R, CHEBUDE Y and DÍAZ I (2013) Natural zeolites from Ethiopia for elimination of fluoride from drinking water. Sep. Purif. Technol. DOI: http://dx.doi.org/10.1016/j.seppur.2013.10.006.

GRAN G (1952) Determination of the equivalence point in potentiometric titrations Part II. Analyst 77 661-671.

GUO Q and GUO Q (2013) Water defluoridation by hydrotalcite and takovite and subsequent formation of new fluoride-bearing phases. Environ. Technol. 34 1053-1062.

HUBER AC and MOSLER H (2012) Determining behavioral factors for interventions to increase safe water consumption: a cross-sectional field study in rural Ethiopia. Inter. J. Environ. Health Res. 23 1-12.

KARAMILIDIS AK and DZOMBAK DA (2010) Surface complexation modelling: Gibbsite. Wiley, New Jersey. 294 pp.

KIM HJ, LEE HC and LEE JS (2007) ${ }^{27} \mathrm{Al}$ triple-quantum magic-angle spinning nuclear magnetic resonance characterization of nano structured alumina materials. J. Phys. Chem. 111C 1579-1583.

KLOOS H and TEKLE-HAIMANOT R (1999) Distribution of fluoride and fluorosis in Ethiopia and prospects for control. Trop. Med. Inter. Health 4 355-364.

LARSEN MJ, PEARCE EIF, and RAVNHOLT G (1994) The effectiveness of bone char in the defluoridation of water in relation to its crystallinity, carbon content and dissolution pattern. Arch. Oral Biol. 39 807-816.

LOUNICI H, ADOUR L, BELHOCINE D, ELMIDAOUI A, BARIOU $B$ and MAMERIA N (2001) Novel technique to regenerate activated alumina bed saturated by fluoride ions. J. Chem. Eng. 81 153-160.
MACKENZIE KJD and SMITH ME (2002) Multinuclear Solid-State NMR of Inorganic Materials. Pergamon Press, New York.

MALIYEKKAL SM, SHUKLA S, PHILIP L and INDUMATHI MN (2008) Enhanced fluoride removal from drinking water by magnesia-amended activated alumina granules. J. Chem. Eng. 140 183-192.

MOGES G, ZEWGE F and SOCHER M (1996) Preliminary investigations on the defluoridation of water using fired clay chips. J. Afr. Earth Sci. 21 479-482.

MÜLLER B (1992) ChemEQL V2.0. Swiss Federal Institute of Environmental Science and Technology, Kastanienbaum, Switzerland.

MULUGETA E, ZEWGE F, JOHNSON CA, and CHANDRAVANSHI BS (2014) A high-capacity aluminium hydroxide-based adsorbent for water defluoridation. Desalin. Water Treat. 52 5422-5429.

NIGUSSIE W, ZEWGE F and CHANDRAVANSHI BS (2007) Removal of excess fluoride from water using waste residue from alum manufacturing process. J. Hazardous Mater. 147 954-963.

OSTERWALDER L, JOHNSON CA, YANG H and JOHNSTON RB (2014) Multi-criteria assessment of community-based fluorideremoval technologies for rural Ethiopia. Sci. Total Environ. 488 532-538.

ROBERT CTS, JENNIFER CS and IAN MT (1991) ${ }^{27}$ Al nuclear magnetic resonance spectroscopy investigation of thermal transformation sequences of alumina hydrates. J. Mater. Chem. 1 875-879.

SCHOEMAN JJ (2009) Performance of a water defluoridation plant in a rural area in South Africa. Water SA 35 97-101.

SHIMELIS B, ZEWGE F, and CHANDRAVANSHI BS (2006) Removal of excess fluoride from water by aluminium hydroxide. Bull. Chem. Soc. Ethiop. 20 17-34.

SNEHA J, MAHESH KY, NITIN L and SADHANA R (2012) Fluoride in drinking water and defluoridation of water. Chem. Rev. 112 2454-2466.

STEBBINS JF, KROEKER S, LEE SK and KICZENSKI TJJ (2000) Quantification of five- and six-coordinated aluminium in aluminosilicate and fluoride-containing glasses by high-field, high-resolution ${ }^{27}$ Al NMR. Noncryst. Solids 275 1-6.

STUMM W (1992) Chemistry of the Solid-Water Interface. WileyInterscience, New York.

SUNG KL, SUN YP, YOO SY and JAEHYUN M (2010) Structure and disorder in amorphous alumina thin films: Insights from highresolution solid-State NMR. J. Phys. Chem. C114 13890-13894.

TENG SX, WANG SG, GONG WX, LIU XW and GAO BY (2009) Removal of fluoride by hydrous manganese oxide-coated alumina: performance and mechanism. J. Hazard. Mater. 168 1004-1011.

TRIPATHY SS and RAICHUR AM (2008) Abatement of fluoride from water using manganese dioxide coated activated alumina. J. Hazard. Mater. 153 1043-1051.

URRETAVIZCAYA G, CAVALIERI AL, PORTO-LOPEZ JM, SOBRADOS I and SANZ J (1998) Thermal evolution of alumina prepared by the sol-gel technique. J. Mater. Synth. Proc. 61-7.

USEPA (UNITED STATES ENVIRONMENTAL PROTECTION AGENCY) (2008) U. S. National Secondary Drinking Water Regulations. USEPA, Washington, D.C.

WEINGARTNER F and LIEBERTZ J (1978) Granular active alumina with high apparent density and high mechanical durability. United States, Swiss Aluminium Limited (Chippis, CH), Patent No. 4083911. URL: http://www.freepatentsonline.com/4083911.html (Accessed 24 August 2013).

WHO (WORLD HEALTH ORGANIZATION) (2011) Guidelines for Drinking Water Quality (4 ${ }^{\text {th }}$ edn.). WHO, Geneva.

YANG X, SUN Z, WANG D and FORSLING W (2007) Surface acidbase properties and hydration/dehydration mechanisms of aluminium (hydr)oxides. J. Colloid Interf. Sci. 308 395-404. 